\title{
Youth leadership life skills development of participants in the West Virginia 4-H camping program
}

\author{
Rebecca Diane Duncan \\ West Virginia University
}

Follow this and additional works at: https://researchrepository.wvu.edu/etd

\section{Recommended Citation}

Duncan, Rebecca Diane, "Youth leadership life skills development of participants in the West Virginia 4-H camping program" (2000). Graduate Theses, Dissertations, and Problem Reports. 1085.

https://researchrepository.wvu.edu/etd/1085

This Thesis is protected by copyright and/or related rights. It has been brought to you by the The Research Repository @ WVU with permission from the rights-holder(s). You are free to use this Thesis in any way that is permitted by the copyright and related rights legislation that applies to your use. For other uses you must obtain permission from the rights-holder(s) directly, unless additional rights are indicated by a Creative Commons license in the record and/ or on the work itself. This Thesis has been accepted for inclusion in WVU Graduate Theses, Dissertations, and Problem Reports collection by an authorized administrator of The Research Repository @ WVU. For more information, please contact researchrepository@mail.wvu.edu. 


\title{
YOUTH LEADERSHIP LIFE SKILLS DEVELOPMENT OF PARTICIPANTS IN THE WEST VIRGINIA 4-H CAMPING PROGRAM
}

\author{
Rebecca D. Duncan
}

\author{
Thesis submitted to the \\ College of Agriculture, Forestry, and Consumer Sciences \\ at West Virginia University \\ in partial fulfillment of the requirements \\ for the degree of \\ Master of Science \\ in \\ Agricultural and Environmental Education
}

Stacy A. Gartin, Ph.D., Chair

Patricia A. Mulkeen, Ph.D.

Layle D. Lawrence, Ph.D.

Division of Resource Management

Morgantown, West Virginia

2000

Dr. Stacy A. Gartin

Major Advisor 


\title{
ABSTRACT \\ YOUTH LEADERSHIP LIFE SKILLS DEVELOPMENT OF PARTICIPANTS IN THE WEST VIRGINIA 4-H CAMPING PROGRAM
}

\author{
Rebecca D. Duncan
}

\begin{abstract}
Although the development of leadership skills through the 4-H camping program is highly valued, measurement of leadership skill development of West Virginia 4-H camping program participants has been lacking. Thirteen to fifteen year old 4-H members were targeted in this study in order to gather data about leadership development among this age group.

Significant relationships were found between the total YLLSDS score and years of participation in county camp and receiving the Spirit of Camp Award. Participants also reported higher leadership scores if they had served as a Chief or Sagamore of their 4-H tribe, if they were female, and if they were younger.

Leadership activities, opportunities, and training in the 4-H camping program vary greatly from county to county in West Virginia. Uniform goals, programming, and evaluation are needed to facilitate leadership programming, life skills development, and leadership evaluation for the West Virginia camping program.
\end{abstract}




\section{ACKNOWLEDGMENTS}

I am extremely grateful to my committee members for their support, wisdom, and pushes along the way to keep going. Specifically, to my major advisor, committee chair, and friend, Dr. Stacy Gartin. You have always listened to all of my ranting and raving, and offered advice when I needed it. You are an exceptional person who has provided me with a world of opportunities with your teaching. I'll miss 262. I can only say Thank You.

Dr. Patty Mulkeen, I couldn't have done this without you. Your guidance, encouragement, and advice have made this possible. Thanks for the statistics training! You understand my great love for 4-H and camping. I hope I will have the opportunity to work with you again to make a difference in 4- $\mathrm{H}$ and the 4-H camping program.

To Dr. Jean Woloshuk, who despite the busiest schedule took my thesis on with exuberance. 4-H couldn't ask for a more dedicated hard working person than you. I deeply appreciate your advice, guidance, and time.

Dr. Layle Lawrence always offered kindness and advice and has always been able to make me smile. You have provided me with many opportunities, including the opportunity to teach Ag. Mechanics. I had a great time and I have learned a great deal from you.

Dr. Kerry Odell, who graciously stepped in when he was needed, offered sound advice and encouragement, and a friendly smile to go along with it. Thanks!

Tim, it's finally done, you may now have your wife back. Thanks for being so supportive and understanding of my love in 4-H and my work.

Thanks to all the West Virginia 4-Hers that completed their surveys and did indeed try to make the best better. 


\section{TABLE OF CONTENTS}

Page

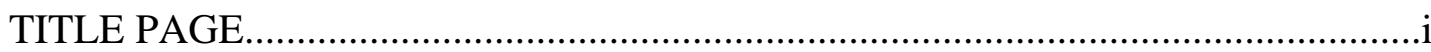

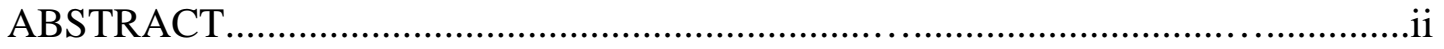

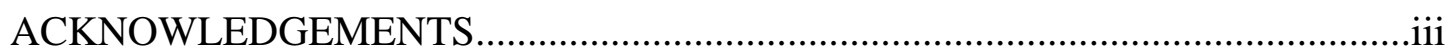

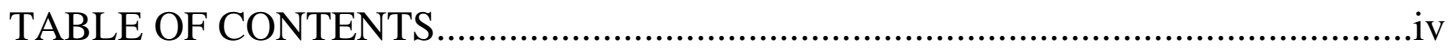

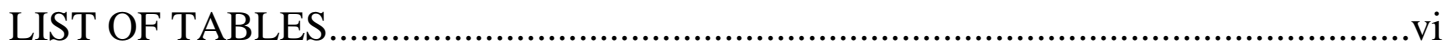

\section{CHAPTER}

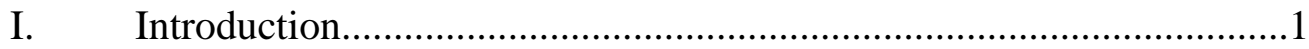

The 4-H Program............................................................................. 1

The 4-H Camping Program.......................................................... 3

Statement of the Problem...................................................................4

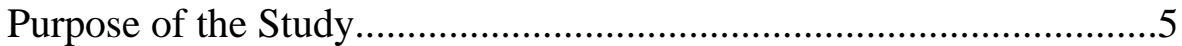

Objectives of the Study...............................................................5

Limitations of the Study ........................................................6

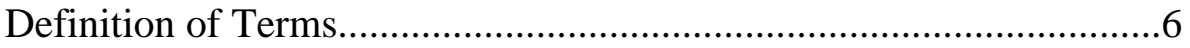

II. Review of Literature

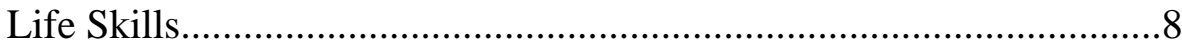

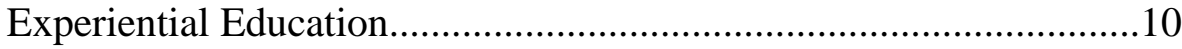

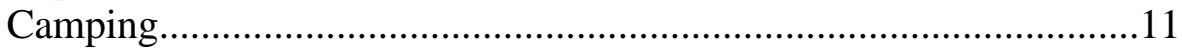

Summary of Literature Review................................................13

III. Methodology

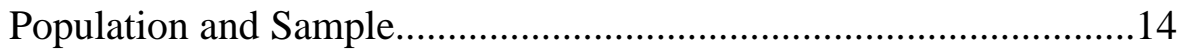

Description of Design...............................................................15

Development of the Instrument................................................15

The Youth Leadership Life Skills Development Scale.(YLLSDS)....16

Data Collection Procedures.............................................................18

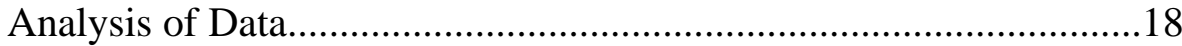

Use of Findings................................................................... 19 
IV. Findings

Survey Return Information............................................................20

Response Bias...................................................................21

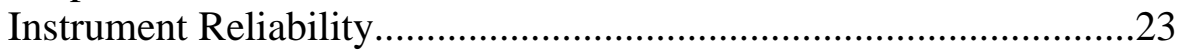

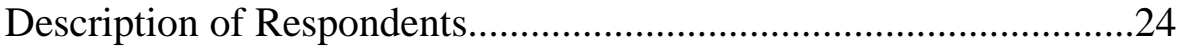

YLLSDS Response Ratings........................................................27

Correlations of YLLSDS with Demographic Data..........................27

Correlations of YLLSDS Sub-Scale Ratings

With Demographic Data...................................................29

Correlations of YLLSDS with 4-H related variables.......................31

Correlation of YLLSDS Sub-Scales with 4-H related variables......................................................... 31

V. Summary, Conclusions, and Implications

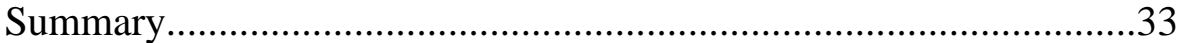

Conclusions.........................................................

Implications..............................................

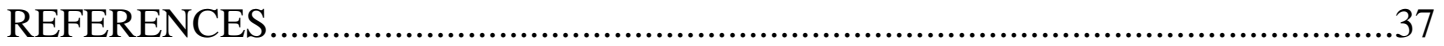

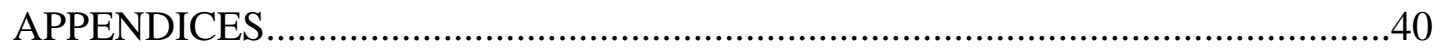

APPENDIX A: Cover Letter to 4-H Members..........................................41

APPENDIX B: Cover Letter to Parents.........................................................43

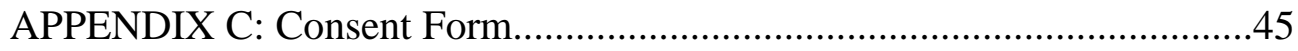

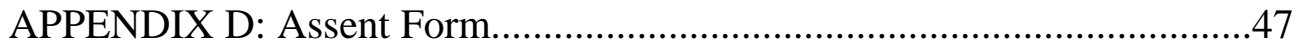

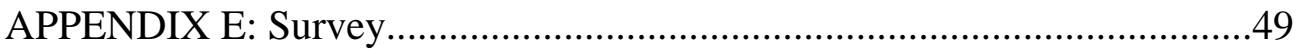




\section{LIST OF TABLES}

$1 \quad$ Youth Leadership Life Skills Development Scale

Page

Sub-domains, Indicators, and Instrument Item Numbers........................... 17

2. Number of surveys or reminders mailed and

associated response rate following each phase of data collection

3. Grand Means and Analysis of Variance Results

for YLLSDS Sub-scales by Early and Late Respondents.

4. Cronbach's Alpha of YLLSDS Sub-scales.

5. Gender, Age, Ethnicity, and Place of

Residence of Respondents

6. Descriptive Statistics for Years in 4-H, Years at County

Camp, Years at State Camp, Years of Teen Leadership, \&

Years of Taking Leadership Project.

7. Mean Importance Ratings and Standard Deviations for the

Youth Leadership Life Skill Development Scale Items

8. Analysis of Variance Examining Effects of Age,

Ethnicity, Gender, and Place of Residence on

Youth Leasdership Life Skills Development Total Score

9. Analysis of Variance Examining 4-H Related

Variables on Youth Leasdership Life Skills

Development Total Score.

10. Correlations of the YLLSDS with selected 4-H Variables 


\section{CHAPTER 1}

Introduction

4-H is one of the largest youth organizations in the world, serving over five million youth in the United States (National 4-H Council, 1999). The organization's roots lie in the teaching of agriculture to rural youth through a "learning by doing" approach. In the early 1900's, boys were instructed in farming practices and often held corn-growing contests, while girls were instructed in canning and home economics.

During the 1916-1920 era, boy's and girl's club work began to focus on the individual development of youth. W.H. "Teepi" Kendrick, West Virginia's state 4-H club leader, began to talk about 4-H in a developmental context using a four-fold developmental approach of Head, Heart, Hands, and Health, which is still used today (Stewart, 1969). Kendrick believed "If a boy or girl would develop his H's, then he would become a trained leader, and this was a goal-the primary one" (Stewart, 1969, p. 25).

4-H now offers a wide variety of programs and projects where members can learn about Citizenship and Civic Education, Communications and Expressive Arts, Consumer and Family Sciences, Environmental Education and Earth Sciences, Personal Development and Leadership, Plants and Animals, and Science and Technology. 4-H programming has diversified to ensure "the development of youth as individuals and as responsible and productive citizens" which is the organization's objective (National 4-H Council Online, 1999).

4-H teaches children self-esteem, cooperation skills, responsibility, leadership, and empathy with people and animals, and about the quickly changing world in which we live (Sauter, 1993). Activities within the 4-H program include projects, clubs, fairs, camps, state, national, and international gatherings. The 4-H Youth Development Program focuses on building 
lifelong learning skills that develop youths' potential, referred to as life skills (United States Department of Agriculture: Focus on the Future, 1994). Hamburg (1989, p. 18) considered life skills as the skills needed for surviving, living with others, and succeeding in a complex society. The targeting of life skills is an important aspect of 4-H and youth development, which combines the theories of four-fold development and life skill development into a manageable tool for curriculum development of 4-H programs. "Youth development experiences of high quality don't just happen. The best ones are carefully planned..." (Hendricks, 1996 p. 5).

Two of the ways that the 4-H program achieves developing youth life skills are through 4-H clubs and camping. 4-H clubs may be community or neighborhood based, and may be organized within a school or conducted at a school's facilities. In West Virginia, children must reach the age of 9 during the 4-H year (October 1 - September 30) and/or be younger than 21 to join 4-H. Presentations of 4-H projects at club meetings also help to teach 4-H members how to convey their ideas to others. 4- $\mathrm{H}$ members take projects, present information regarding their projects to club members at meetings. The 4-Her must present his or her project in a way that allows the audience to understand what that project is about and what that 4-H'er is doing to complete his/her project requirements. Group discussions and activities also provide members with opportunities to practice group interaction and to become aware of group dynamics (Jackson, 1997).

4-H clubs help youth understand changes in families, communities, and society. 4-H clubs focus on the importance of work, responsibility, and individuality enabling youth to achieve success. 4-H programs teach members about the responsibilities of citizenship in the community, country, and world. 4-H clubs assist youth with decision-making, problem solving skills, and group dynamics (Jackson, 1997). 
4-H camping can be one of the most intensive methods of youth interaction. Campers are exposed to group living conditions and activities, which help them to develop interpersonal skills and self-confidence (Jackson, 1997). West Virginia held the very first county 4-H camp on a farm in Randolph County in August of 1915. It was called Camp Good Luck (This is 4-H, 1967). West Virginia also held the very first state camp in 1922 at Jackson's Mill State 4-H Conference Center in Lewis County (Stewart, 1969, p. 49). State camps were originally created because a larger camp could provide the proper leadership training that campers needed (Stewart, 1969).

The 4-H camping program in West Virginia offers several fun-filled activities including classes, crafts, recreation, contests, singing, and council circle. One of the goals of camping is for campers to "learn and practice leadership skills, and fulfill leadership roles" (USDA Camping Handbook, 1983, p. A3). Leadership roles come in many forms at camp. Youth can practice leadership through becoming a chief or sagamore of their tribe or by being given some other creative task such as writing the tribal songs, developing the tribal challenges, or by serving as a song leader. Youth also develop abilities to work as a group through the completion of tribal duties, or by participating in tribal activities such as deciding on tribal challenges, completing scavenger hunts, and participating in tribal meetings.

West Virginia county 4-H camps may last from 4 to 7 days and are residential with campers spending days and nights at the camping facility. In addition to county camps, West Virginia also offers three state camps: Alpha I, Alpha II, and Older Members' Conference (OMC). The purpose of the Alpha camps is to "provide 4-H members with personal development experiences to help better understand themselves, and to display more personal confidence when assuming leadership positions" (WVU Extension Service 4-H Event Packet, 1999). Alpha camps are limited to West Virginia 4-H members entering $6^{\text {th }}$ grade and up; campers are recommended 
by their county extension office. Alpha camps are operated for six days and are held at Jackson's Mill, State 4-H Conference Center.

Older Members Conference involves youth entering $9^{\text {th }}$ grade and up who are also recommended by the county extension office. OMC exists "to develop leadership among older 4H members" (WVU Extension Service 4-H Event Packet, 1999) and also operates for 6 days. OMC also selects 25 4-Hers who participated in OMC the previous year to serve as discussion leaders and who are trained before OMC on small group skills and dynamics. Discussion leaders engage groups at $\mathrm{OMC}$ in various topics that affect today's youth.

With the myriad of leadership opportunities in the 4-H club and camping programs, 4- $\mathrm{H}$ members are given several ways to develop leadership life skills. To date, however, the level of leadership life skills development of 4-H members has yet to be examined in West Virginia. An indication of leadership life skills must be offered to provide information to Extension professionals assessing the impact of $4-\mathrm{H}$ on youth and their leadership development within the 4-H program. If the objective of 4-H is to promote youth development, responsibility, and citizenship, some measurement must be taken to determine if the objectives of this organization are being met and to what degree. This study will examine the developmental outcomes of 4-H campers and leadership life skills compared to those of club members who do not attend 4-H camp. This evaluation of youth leadership life skill development is essential to facilitate the improvement leadership development in the West Virginia 4-H camping program.

\section{Purpose of the Study}

The purpose of this study was to investigate relationships that exist between youth leadership life skill development and 4-H camp participation. 4-H members participating in the 1998-1999 club year, ages 13 through 15, were asked about their 4-H camping participation and 
leadership life skill development as it relates to their 4-H camping experiences. The results of this study will be provided to Extension Service personnel to assist with statewide planning and evaluation of 4-H camping programs. Results will also be provided to county Extension agents to reinforce countywide camping program development and evaluation aimed at increasing youth development objectives in the area of leadership development.

\section{Objectives of the Study}

1. Describe the respondents' demographic characteristics related to age, gender, ethnicity, and place of residence.

2. Describe respondents' self-perceived gain of leadership life skill development as a result of the 4-H camping experience measured by the Youth Leadership Life Skills Development Scale.

3. Determine the relationships between members' self-perceived gain of leadership life skill development and age, ethnicity, gender, place of residence.

4. Determine the relationship between participation in the 4-H camping program and members' self-perceived gain of leadership life skills development by examining years in 4-H, years at county camp, years at state camp, teen leadership, being elected as an officer of a 4-H club, being a chief or sagamore of a 4-H tribe, or receiving specific awards.

\section{Limitations of the Study}

The sample was limited to $4-\mathrm{H}$ members 13 to 15 years of age, participating in the 4-H camping program during the 1998-1999 club year in West Virginia. County Extension Agents in Braxton and Lewis counties refused the study in their counties. 


\section{Definition of Terms}

4-H: A program carried out by the United States Department of Agriculture in connection with land-grant universities. The program emphasizes a four-fold developmental approach involving the Head, Heart, Hands, and Health.

4-H Club: A group of 4-H members that is organized with an adult leader and youth officers which has meetings throughout the year in a local or school setting.

4-H Camp: For the purposes of this study, a large gathering of 4-H members for the period of 4-7 days involving tribal competitions, sporting events, recreation, assemblies, council circle, and other activities. Activities may vary from camp to camp in West Virginia thus all activities cannot be listed.

Extension Service: The organization, which conducts various informal education programs for people of the United States. The mission of the West Virginia University Extension Service is "to form learning partnerships with the people of West Virginia to enable them to improve their lives and communities. To these partnerships, we bring useful research- and experience-based knowledge that facilitates critical thinking and skill development”.

Project: A method by which 4-H members are taught specific information and skills relating to the areas of Citizenship and Civic Education, Communications and Expressive Arts, Consumer and Family Sciences, Environmental Education and Earth Sciences, Personal Development and Leadership, Plants and Animals, and Science and Technology.

Life Skills: The skills needed for surviving, living with others, and succeeding in a complex society (Hamburg, 1989, p. 18).

Leadership Life Skills: Self-assessed and organization-specific, development of life skills necessary to perform leadership functions in real life (Miller, 1976, p2). 


\section{CHAPTER II}

Review of Literature

The purpose of this study was to identify relationships that exist between youth leadership life skills development and 4-H camp participation among 1998-1999 West Virginia 4-H members age 13-15. Specific aspects of examination will include: self-perceived gain of youth leadership life skills development as measured by the Youth Leadership Life Skills Development Scale, participation and involvement in 4-H leadership activities, and selected demographic variables.

\section{$\underline{\text { Life Skills }}$}

The Carnegie Council on Adolescent Development (1992) believes that young adolescents seek out opportunities to develop life skills. Hendricks (1996, p4) defines life skills as "those skills that help an individual to be successful in living a productive and satisfying life." Hamburg (1989) defined the training of life skills as the formalized teaching of the skills needed for surviving, living with others, and succeeding in a complex society. Lang and Gerwig (1989) discussed the development of skills that help youth cope with a changing world full of social pressures. Glenn and Nelson (1987) refer to their "significant seven" as skills that are necessary for success during ones lifetime, but they do have to be developed, and they have to be maintained in order to enjoy continued success.

Scales, (1986) follows a back-to-the-basics approach in life skills development and education, focusing on often neglected thinking and reasoning skills. Three components are included in that approach: (1) to encourage young people to consider information of all kinds, selecting some, rejecting some; (2) to enable them to make choices about and be critical 
consumers of both products and relationships; and (3) to teach them to help themselves and others through activism and social involvement.

Miller (1991b) believed that a strong life skills foundation involving the mastery of intellectual, physical, emotional, and social tasks could assist individuals in coping with the changes they are experiencing while progressing from childhood to adulthood. Miller focused on the developmental tasks derived by Havighurst (1972) that are to be mastered during adolescence. Many variables in the social environment of the adolescent are changing rapidly. The school setting changes to a setting of multiple classes, reduced contact with teachers, and little continuity from one class period to the next. Preparation for other adult roles and responsibilities such as worker, parent, citizen, and spouse also occur during this period (Van Horn, 1986). "Developing an individual style of coping with these developmental tasks is critical in determining how effectively the adolescent deals with the many changes" they are facing (Miller, 1991b, p7).

During adolescence, several important challenges occur such as adjusting to physical changes, establishing intimate personal relationships, reassessing values, and achieving gradual independence from adults (Adams \& Gulotta, 1983). By positively resolving the crises of adolescence, a person should become a capable and mature individual with a well-defined identity (Miller, 1991b). Learning that one is competent and capable of work, locating oneself in the social world, and developing intimate involvement with another are some of the essential ingredients in a successful transition from adolescence to adulthood (Adams \& Gulotta, 1983; Erikson, 1968).

Based on the ideas of educational theorists, developmental psychologists, and experiential education advocates, Weatherford and Weatherford (1987) identified three areas of 
life skills development enhanced by $4-\mathrm{H}$ project materials: competency, coping, and contributory. They defined competency skills as developing knowledge of and understanding about self and the world around them; coping skills as developing identity through the development of interpersonal skills; and contributory skills as increasing, sharing, and social contribution skills which allow self and others to overcome situations and personal barriers.

\section{Experiential Education}

The learning of life skills occurs within an educational context known as experiential education. Conrad (1979, p. 32) stated, "psychologically, growth occurs through significant interactions with the environment, (experience) learning and development is an interactive process." Conrad and Hedin (1981) defined experiential education as "educational programs offered as an integral part of the general school curriculum, but taking place outside the conventional classroom, where students are in new roles featuring significant tasks with real consequences and where the emphasis is on learning by doing with associated reflection."

Research has supported the effectiveness of life skill development and experientially based programs such as 4-H. Hedin (1983) found that students who participated in experientially based programs, entered into more relationships with adults and experienced more positive attitudes toward them. Youth also developed more responsible attitudes and behaviors, valued community participation more highly, experienced more positive attitudes toward careers, experienced positively affected self-concepts and self-esteem in relation to others, a majority learn more, and moved toward more empathy and complexity.

Hamburg (1989) found that successful youth development programs taught youth skills in decision-making, social skills such as communications, interpersonal strategies, and selfregulation. Other successful programs involved peer teachers and leaders, interaction with 
significant adults, and the use of cooperative learning to foster a teamwork attitude. Programs that were most effective at achieving life skill development involved parents and linked youth with the community. Experiential learning or learning by doing, has been a primary philosophy of 4-H since its beginning (Weatherford \& Weatherford, 1987.)

Previous studies have examined life skill development, specifically leadership life skill development. Studies performed by Boyd, Herring, and Briers and Dormody, Seevers, and Clason, have examined leadership life skills of 4-H members compared to non 4-H members. Results indicated significantly higher leadership life scale scores for 4-H members than the scores of non 4-H members. Research by Dormody, Seevers, and Clason involving other organizations such as FFA has yielded similar results.

\section{Camping}

The West Virginia 4-H camping program provides an autonomy-oriented approach to life skill development. O'Brien, Pavlicin, Lister, and Schultz (1995) put forth that when campers know the boundaries, they are free to work within them because the structure is not confining. Thomas (1996) states that camp activities promote natural leadership and character building, with youth developing self-awareness, communication skills, interpersonal skills, and ethics and responsibilities associated with leadership. O'Brien et al (1995) draw more attention to interpersonal and communication skills by pointing out that children who eat, sleep, live, and play with other people every day for a week learn to get along with each other despite their personal backgrounds. Some children may be shy, others outgoing, and some have never had to share personal space such as a bedroom before.

At camp, children are encouraged to participate in all activities, and are evaluated on their willingness to try, rather than ability to succeed at the desired task. Campers also learn to express 
themselves in a non-threatening, nurturing environment (O'Brien et al, 1995). Campers can get up in front of the entire camp and perform a skit, sing, and a variety of other activities. 4-H camp also offers youth with formal leadership positions such as song leader, sagamore, chief, junior leader, and junior counselor. Placing youth in such positions gives them responsibility and lets them experiment with and practice leadership roles. The chief and sagamore also must develop good group dynamics, as they must operate tribal meetings with order to accomplish set tasks. It is with this in mind that the need for formally evaluating the West Virginia 4-H camping program becomes evident. 4-H camps provide a fun, yet meaningful way for children to accomplish learning, yet are 4-H campers adequately developing leadership life skills as much as we think they are?

The findings of this study will provide a means for Extension personnel in West Virginia to measure and evaluate the level of leadership of its young people. By examining leadership life skills development Extension personnel will have a better grasp of where youth are in their development of those skills and be able to develop realistic leadership goals for 4-H youth.

\section{$\underline{\text { Summary of Literature Review }}$}

Within this chapter, literature and research related to the concept of 4-H leadership life skill development has been explored. Life skills and experiential education provide a basis for the developmental goals of West Virginia 4-H members.

Life skills refer to skills "needed to survive, live with others, and succeed in a complex society (Hamburg, 1989). Life skills education assists youth with personal development skills and helps to ensure a successful future.

The 4-H program focuses on building lifelong learning skills that develop youths' potential. Leadership development experience involves active involvement by participants. The 
West Virginia 4-H camping program allows youth to learn and practice individual leadership styles and roles through its various camp activities.

If youth are to succeed in today's complex society, improvements in the design of 4- $\mathrm{H}$ leadership life skills programming are imperative. The only way to achieve this is to examine the level of leadership life skills of current 4-H members, and re-design/evaluate current programs as necessary to maintain or increase those levels. 


\section{CHAPTER III}

\section{Methodology}

The purpose of this study is to investigate relationships that exist between youth leadership life skill development and 4-H camp participation. 4-H members participating in the 1998-1999 club year, ages 13 through 15, will be asked about their 4-H participation and leadership life skill development as it relates to their 4-H camping experiences. The results of this study will be provided to Extension Service personnel to assist with statewide planning and evaluation of 4-H camping programs. Results will also be provided to county Extension agents to reinforce countywide camping program development and evaluation aimed at increasing youth development objectives in the area of leadership development.

\section{Objectives of the Study}

5. Describe the respondents' demographic characteristics related to age, gender, ethnicity, and place of residence.

6. Describe respondents' self-perceived gain of leadership life skill development as a result of the 4-H camping experience measured by the Youth Leadership Life Skills Development Scale.

7. Determine the relationships between members' self-perceived gain of leadership life skill development and age, ethnicity, gender and place of residence.

8. Determine the relationship between participation in the 4-H camping program and members' self-perceived gain of leadership life skills development by examining years in 4-H, years at county camp, years at state camp, teen leadership, being elected as an officer of a 4-H club, being a chief or sagamore of a 4-H tribe, or receiving specific awards. 


\section{Population and Sample}

The population for this study was all 4-H campers between the ages of 13 and 15 as of the 1998-1999 club year who live in West Virginia. Using data obtained from West Virginia University 4-H Extension Specialists (ES237 data), the population was determined to be $\mathrm{N}=$ 3875. The sample size was determined to be 351 by using Krejcie and Morgan (1960) Determining Sample Size for Research Activities. The sample size was then rounded up to 400. A simple random sampling method was used to obtain names and mailing addresses for 4-H members excluding those in the counties of Lewis and Braxton in West Virginia. These counties were excluded because their agents did not wish their 4-H members to participate in the study.

\section{Description of Design}

This study used a descriptive, correlational research design. This type of research methodology provides for the generation of large amounts of data in a limited time frame (Kaplin, 1991, p24.). A correlational design only allows for the discovery, clarification, and explanation of relationships between and among research variables, rather than a cause and effect explanation (Borg and Gall, 1989).

The dependent variable in this study was self-perceived gain of leadership life skill development of 4-H campers as measured by the YLLSDS. The independent variables were serving as a chief or sagamore at 4-H camp, being a teen leader, gender, age, ethnicity, place of residence, years in 4-H, specific awards received, and years of attendance at 4-H county and/or state camp. Measurement of the dependent variable has taken place after the treatments have occurred (ex post facto).

The measurement of all variables was achieved using the "Assessing Leadership Skills Gained Through The West Virginia 4-H Camping Program" survey instrument. The researcher 
performed no manipulation of the independent variables. The research design did not allow for a causal relationship between the dependent and independent variables. Analyses of variance (ANOVA) were used to summarize the magnitude and direction of variable relationships along with linear regression analyses.

\section{Development of the Instrument}

The survey instrument utilized in this study was “Assessing Leadership Skills Gained Through the West Virginia 4-H Camping Program." The survey form consisted of two parts. Part one of the survey inquired about the development of youth leadership life skills, using the original Youth Leadership and Life Skills Development (YLLSDS) questionnaire developed by Dormody, Seevers, and Clason (1993). Written permission from the authors was obtained to use the YLLSDS instrument for this study. Part two of the survey deals with age, gender and demographic information and information related to 4-H camping involvement. A consent form (Appendix B) and assent form (Appendix C) were included to meet requirements of the Human Subjects Review Board at West Virginia University. A cover letter (Appendix A) explained the purpose of the study and gave directions for completing and returning the questionnaire. The letter was signed by the researcher and her major advisor with a self-addressed, stamped envelope to facilitate the prompt return of the questionnaire. A copy of the instrument used in this study can be found in Appendix D.

The Youth Leadership and Life Skills Development Scale (YLLSDS)

The YLLSDS scale was developed by Seevers, Dormody, and Clason to provide a "valid, reliable scale to measure youth leadership life skills development" (1995, p. 29) for both 4-H and FFA members. The YLLSDS scale was based on the concept of youth leadership life skill development created by R. Miller (1975 \& 1976) as well as the concept of leadership life skills 
having seven sub-domains.

Seevers, Dormody, and Clason (1995 p30) used 68 indicators categorized into the seven

sub-domains from Miller (1976) from the following sources:

The indicators were comprised of the 60 indicators developed in 4- $\mathrm{H}$ by Miller (1976), three indicators from Miller (1975), two indicators dealing with manners and personal appearance, one indicator dealing with decision making from Harp (1984) and two researcher-developed indicators with the first related to problem solving and the second related to learning by doing based on the 4- $\mathrm{H}$ and FFA mottos.

Face and content validity of the YLLSDS were assessed by:

1. 66 of the 68 indicators were from the seven sub-domains identified by the literature review.

2. A panel of seven experts representing New Mexico Cooperative Extension Service administrators, plus vocational education, educational administration, and research methods and statistics faculty members.

The following procedures were performed to reduce the original 68 indicators to the 30-

indicator scale now used (Seevers et al. 1995 p31):

The 68 indicators included in the scale were reduced by several procedures. Item analysis procedures (Ary, Jacobs, \& Razavieh, 1990) were performed looking for low variance and extreme skewness as a test of construct validity (6 indicators were eliminated). Internal structure validity centered on the relationship of each indicator to the other eliminating those with an inter-item correlation below .40 ( 26 indicators were eliminated). Cross structure construct validity was evaluated within the context of those indicators of other concepts, known to have a relationship with youth leadership life skills development from the literature. The researchers searched for a correlation with one or more of the validators that was greater than or equal to .20 , plus any relationships that were in the opposite direction of relationships found in the literature. Six indicators had a low association with years in 4-H or FFA and were eliminated. No opposing relationships were found.

The final scale now known as the Youth Leadership Life Skills Development Scale (YLLSDS) scale was comprised of 30 items. Table 1 represents the item numbers that correspond with each of the seven subscales represented by Miller (1976 \& 1976). 
Table 1

Youth Leadership Life Skills Development Scale sub-domains, Indicators, and Instrument Item Numbers (Morris, 1996).

\begin{tabular}{lll}
\hline Conceptual Sub-Domain & Numbers of Indicators & Item Numbers \\
\hline Communication Skills & 2 & 3,15 \\
Decision Making Skills & 5 & $1,4,8,16,19$ \\
Skills in Getting Along with Others & 7 & $5,9,17,20,23,25,29$ \\
Learning Skills & 4 & $6,10,21,27$ \\
Management Skills & 3 & $7,28,30$ \\
Skills in Understanding Self & 6 & $2,12,13,22,24,26$ \\
Skills in Working with Groups & 3 & $11,14,18$ \\
\hline
\end{tabular}

The YLLSDS was administered to senior New Mexico 4-H and FFA members with 262 surveys analyzed. The YLLSDS, when examined for reliability, resulted in a Cronbach's Alpha coefficient of .98. When testing for dimensionality, the authors stated that "the factor loading produced was incoherent; no reasonable interpretations of the factor loading were found" (Seevers, Dormody, and Clason, 1995, p. 33). They concluded that, "although the scale was derived from seven original conceptual sub-domains, youth in the population appear to perceive the construct as unidimensional" (p. 33).

\section{$\underline{\text { Data Collection and Procedures }}$}

The cover letter to respondents and their parents explained the research study, why the respondent's participation was important, how much time it would take them to complete the survey, instructions for returning the completed questionnaire, assurance of confidentiality, and a non-obligation statement. The final survey was prepared in green and included a cover letter on WVU Extension Service Letterhead, a consent form, and an assent form. A thank you for taking the time to complete the survey was included, along with a 4-H sticker. Surveys were coded for 
the purpose of sending reminder post cards. A self-addressed stamped envelope was provided to speed the return of the questionnaires.

Procedures for administering mail questionnaires as recommended by Dillman (1978) were followed to increase response rate. Two weeks after the initial survey was mailed, a reminder post card was sent. An additional survey was mailed two weeks after the reminder card for the remaining non-respondents.

\section{Analysis of Data}

This study examined the level of leadership life skill development of West Virginia 4-H camping participants between the ages of 13 and 15 . The data collected as a result of this study were analyzed using the Statistical Package for Social Sciences version 9.0. Analysis of variance, frequencies, means, and regression analyses were used to describe and analyze the data.

\section{$\underline{\text { Use of Findings }}$}

Findings from this study will be provided to the West Virginia University Extension Service in hopes of further development of the West Virginia 4-H state and county camping program. Findings will also be available upon request to county Extension agents and other Extension staff for development and evaluation of county based camping programs. Based upon the results of this study, extension agents will be able to ascertain the leadership levels of 4-H camp participants as measured by the Youth Leadership Life Skills Development Scale and plan 4-H programs accordingly. 


\section{CHAPTER IV}

Findings

The purpose of this study was to investigate relationships that exist between youth leadership life skill development and 4-H camping participation. This information in turn will be provided to the WVU Extension Service for further camping and general 4-H program development. A sample of 400 West Virginia 4-H members were surveyed using the Youth Leadership Life Skills Development Scale (Dormody, Seevers, \& Clason, 1993).

Data obtained as a result of this study were analyzed using the Statistical Package for Social Sciences for Windows (SPSS) version 9.0. Levels of significance were set a priori at $\mathrm{p}<0.05$ for all statistical tests. Means and standard deviations were calculated for each variable where applicable. The data obtained from the YLLSDS portion of the survey were first tabulated using Microsoft Excel to achieve a total score, then entered into SPSS as a variable for analysis. Additionally, the YLLSDS sub-scale values were entered into SPSS for further analysis with each sub-scale having its own variable.

\section{Survey Return Information}

400 surveys were mailed out, 158 completed surveys were returned, representing $39.5 \%$ of the sample. Thirty five $(8.75 \%)$ were returned by the post office for incorrect addresses. Eight $(5.1 \%)$ surveys were completed by respondents less than 13 years old or over 15 years old, putting them outside the target age group for this study. The final set of useable surveys numbered 153 .

The first mailing of surveys occurred on June 4, 1999. This mailing yielded 97 completed surveys. Reminder post cards were mailed to the remaining 268 members of the sample on June 18, 1999. An additional 38 surveys were returned following the reminder post cards. A copy of 
the reminder post card can be found in Appendix F. The second mailing of surveys occurred on July 2, 1999 to 230 members of the sample and 26 additional surveys were returned. Table 2 summarizes the mailing, return and response rate information for each phase of data collection. Table 2.

Number of surveys or reminders mailed and associated response rate following each phase of data collection.

\begin{tabular}{|c|c|c|c|}
\hline & Number Mailed & Number Returned & Response Rate \\
\hline Initial Survey Mailing & 400 & 97 & $24.3 \%$ \\
\hline Reminder Post Card & 268 & 38 & $14.2 \%$ \\
\hline Second Survey Mailing & 230 & 26 & $11.3 \%$ \\
\hline Total & 161 & $40.3 \%$ & \\
\hline
\end{tabular}

Dillman (1972, 1978, 1983, Dillman et al 1974) offered a Total Design Method (TDM) for use in maximizing response rate with mail surveys. Dillman stated, "to my knowledge, no study that has utilized a 12-page or smaller booklet and followed the TDM in complete detail...has obtained less than a 50\% response rate." Several strategies suggested by Dillman were utilized in this study to increase survey response rate including: the ordering of questions to assure that interesting ones related to the topic described in the cover letter come first, the use of a reminder post card, a replacement questionnaire and cover letter, use of Extension service stationery, and a detailed cover letter explaining how confidentiality was maintained (Dillman, 1991).

The strategies of using a reminder post card and a replacement questionnaire did indeed increase the response rate. The response rate may have been reduced, however, by the fact that at the time of mailing, many children were attending 4-H camp, cover letters were singed by the 
researcher's advisor, the researcher, and the 4-H camping specialist, but not by the 4-Hers county agent.

This study was designed to examine the perceived leadership life skill development of 4$\mathrm{H}$ members involved in the general 4-H club program as well as those members involved in the 4-H camping program. Since this study did not include non-4-H members, comparisons between members attending the 4-H camps and those who did not attend 4-H camps were planned to explore differences associated with camp attendance. However, of the 153 useable surveys returned, only $14(9.2 \%)$ were from 4-H members who did not attend camp. This small number of non-campers makes comparison between campers and non-campers problematic. Therefore, further analyses were conducted using only data from the 139 4-H members who attended camp. This decision reduced the sample size even further, however, it also provided greater homogeneity among the sample with regard to their experiences in 4-H, which would also allow any differences in leadership life skill development to be investigated and understood more clearly.

\section{$\underline{\text { Non-Response Bias }}$}

Response bias tests are performed to determine the extent to which respondents might differ from nonrespondents. As this study had a relatively small response rate of $40.3 \%$, it was important to examine response bias levels. It has been suggested that comparing early to late respondents is a qualified test for determining response bias in that late respondents are often similar to nonrespondents (Ary, Jacobs, \& Razavieh, 1996). Therefore, YLLSDS subscale scores for early and late respondents were examined using an analysis of variance (ANOVA).

The analysis of variance is designed to find significant differences among the means of categories and yields an $(\mathrm{F})$ ratio. An F-ratio significant at the $\mathrm{p}<0.05$ level of confidence 
indicates that no more than 5 times out of 100 would a difference of extreme magnitude occur due to sampling fluctuations if the actual difference among means were zero (Ary, D., Jacobs, L.C., \& Razavieh, A. 1990).

All surveys returned from June $8^{\text {th }}$ to July $8^{\text {th }}$ were classified as early $(\mathrm{N}=97)$. All surveys returned from July $9^{\text {th }}$ to August $9^{\text {th }}$ were classified as late ( $\left.N=42\right)$. Respondents' YLLSDS subscale scores were analyzed to determine if any significant differences existed between early and late respondents. No significant differences were observed between early and late respondents YLLSDS subscale scores (see Table 3).

Table 3.

Grand Means and Analysis of Variance Results for YLLSDS sub-scales by Early and Late $\underline{\text { Respondents }}$

\begin{tabular}{lllll}
\hline Sub-Scale & $\begin{array}{l}\text { Overall } \\
\text { Mean }\end{array}$ & $\begin{array}{l}\text { Early } \\
\text { Respondents }\end{array}$ & $\begin{array}{l}\text { Late } \\
\text { Respondents }\end{array}$ & $\begin{array}{l}\text { F } \\
\text { Value }\end{array}$ \\
\hline $\begin{array}{l}\text { Communication } \\
\quad \text { Skills }\end{array}$ & 4.22 & 4.24 & 4.19 & .03 \\
$\begin{array}{c}\text { Decision Making } \\
\quad \text { Skills }\end{array}$ & 9.48 & 9.59 & 9.24 & .37 \\
$\begin{array}{c}\text { Skills to Get Along } \\
\quad \text { With Others }\end{array}$ & 14.74 & 14.96 & 14.24 & .61 \\
$\begin{array}{c}\text { Learning } \\
\quad \text { Skills }\end{array}$ & 7.86 & 7.97 & 7.62 & .39 \\
$\begin{array}{c}\text { Management } \\
\quad \text { Skills }\end{array}$ & 6.07 & 6.21 & 5.76 & 1.09 \\
$\begin{array}{c}\text { Understanding } \\
\quad \text { Self Skills }\end{array}$ & 12.58 & 12.71 & 12.26 & .36 \\
$\begin{array}{c}\text { Skills in Working } \\
\text { With Groups }\end{array}$ & 6.41 & 6.56 & 6.07 & 1.66 \\
\hline
\end{tabular}

After the initial mailing of the survey (June 4, 1999), and the mailing of a post card reminder (Appendix E), a second questionnaire and letter (Appendix F) were sent to those not 
responding by July 1,1999 . August $9^{\text {th }}$ was the date determined as the last day returned surveys would be included in the study.

\section{Instrument Reliability}

In general, the concept of reliability refers to how accurate, on the average; the estimate of the true score is in a population of objects to be measured. Reliability is often measured by Cronbach's alpha, or coefficient alpha. Cronbach's alpha is "the general formula for estimating internal consistency based on a determination of how all items on a test relate to all other items and to the total test" (Gay, 1987, p. 587). An alpha level of 1.00 would indicate a perfectly reliable instrument. The Chronbach's alpha of the YLLSDS for this study was 0.96. Alpha values were also calculated for subscales and are reported in Table 4.

Table 4

Cronbach's Alpha of YLLSDS subscales

\begin{tabular}{ll}
\hline Subscale & Reliability \\
\hline Communication Skills & 0.39 \\
Decision Making Skills & 0.65 \\
Skills in Getting Along with Others & 0.88 \\
Learning Skills & 0.83 \\
Management Skills & 0.70 \\
Skills in Understanding Self & 0.83 \\
Skills in Working with Groups & 0.80 \\
\hline
\end{tabular}

\section{Demographic Characteristics}

Of the 139 respondents, all were current 4-H members participating in the 4-H camping program between the ages of 13 and 15 who were enrolled for the 1998-1999 program year. Each respondent completing the questionnaire was asked to provide his or her gender, age, ethnicity, and place of residence. Descriptive statistics for these characteristics are found in Table 5. 
Table 5

Gender, Age, Ethnicity, and Place of Residence of Respondents

\begin{tabular}{|c|c|c|}
\hline & Frequency & Percent \\
\hline \multicolumn{3}{|l|}{ Gender } \\
\hline Male & 55 & $39.6 \%$ \\
\hline Female & 84 & $60.4 \%$ \\
\hline \multicolumn{3}{|l|}{ Age } \\
\hline 13 & 43 & $30.9 \%$ \\
\hline 14 & 44 & $31.7 \%$ \\
\hline 15 & 52 & $37.4 \%$ \\
\hline \multicolumn{3}{|l|}{ Ethnicity } \\
\hline American Indian/Alaskan native & 0 & $0.0 \%$ \\
\hline Asian or Pacific Islander & 0 & $0.0 \%$ \\
\hline Black, not of Hispanic origin & 0 & $0.0 \%$ \\
\hline White, not of Hispanic origin & 135 & $97.1 \%$ \\
\hline Hispanic & 1 & $0.7 \%$ \\
\hline Missing & 3 & $2.2 \%$ \\
\hline \multicolumn{3}{|l|}{ Place of Residence } \\
\hline Farm & 45 & $32.4 \%$ \\
\hline Town or rural non-farm area & 70 & $50.4 \%$ \\
\hline Larger Town & 20 & $14.4 \%$ \\
\hline City or suburb of a city & 3 & $2.2 \%$ \\
\hline Missing & 1 & $0.7 \%$ \\
\hline
\end{tabular}

Participants reported their length of involvement in various 4-H camping activities from the age of eight. Given a minimum age of eight for 4-H enrollment in West Virginia, this would allow a maximum of seven years of participation in 4-H for 15 year olds. Thirty four (24.5\%) respondents indicated that they had been in $4-\mathrm{H}$ for seven years and $4.3 \%(n=6)$ had been in $4-\mathrm{H}$ for only one year.

With regard to participation in the teen leadership program, $61.2 \%(n=85)$ of respondents had not been involved. This may be due to the fact that the minimum age to participate in this program is thirteen. Of those respondents who were involved in teen leadership, $27.3 \%(\mathrm{n}=38)$ 
Table 6

Descriptive Statistics for Years in 4-H, Years at County Camp, Years at State Camp, Years of Teen Leadership, and Years of Taking The Leadership Project $(\mathrm{N}=139)$.

\begin{tabular}{|c|c|c|}
\hline & Frequency & Percent \\
\hline \multicolumn{3}{|l|}{ Years in 4-H } \\
\hline 1 & 6 & 4.3 \\
\hline 2 & 13 & 9.4 \\
\hline 3 & 11 & 7.9 \\
\hline 4 & 18 & 12.9 \\
\hline 5 & 33 & 23.7 \\
\hline 6 & 24 & 17.3 \\
\hline 7 & 34 & 24.5 \\
\hline \multicolumn{3}{|c|}{ Years at County Camp } \\
\hline 1 & 16 & 11.5 \\
\hline 2 & 24 & 17.3 \\
\hline 3 & 20 & 14.4 \\
\hline 4 & 23 & 16.5 \\
\hline 5 & 23 & 16.5 \\
\hline 6 & 19 & 13.7 \\
\hline 7 & 14 & 10.1 \\
\hline \multicolumn{3}{|c|}{ Years at State Camp } \\
\hline 0 & 103 & 74.1 \\
\hline 1 & 15 & 10.8 \\
\hline 2 & 10 & 7.2 \\
\hline 3 & 7 & 5.0 \\
\hline 4 & 2 & 1.4 \\
\hline 5 & 1 & 0.7 \\
\hline 6 & 0 & 0.0 \\
\hline Missing & 1 & 0.7 \\
\hline \multicolumn{3}{|c|}{ Years of Teen Leadership } \\
\hline 0 & 85 & 61.2 \\
\hline 1 & 38 & 27.3 \\
\hline 2 & 10 & 7.2 \\
\hline 3 & 5 & 3.6 \\
\hline Missing & 1 & 0.7 \\
\hline \multicolumn{3}{|c|}{ Years of Leadership Project } \\
\hline 0 & 100 & 71.9 \\
\hline 1 & 29 & 20.9 \\
\hline 2 & 4 & 2.9 \\
\hline 3 & 4 & 2.9 \\
\hline Missing & 2 & 1.4 \\
\hline
\end{tabular}


had been involved for one year. The majority of respondents $(71.9 \%, n=100)$ had not taken leadership as a 4-H project. Of the remaining respondents, $20.9 \%(n=29)$ reported taking the leadership project for one year. Descriptive statistics for these variables are summarized in Table 6.

4-H members who attend county and/or state camp may qualify for certain leadership roles within the camping program. $4-\mathrm{H}$ members in West Virginia must be in the $6^{\text {th }}$ grade or higher to attend either of the Alpha state camps and must be in the $9^{\text {th }}$ grade or above to attend Older Members Conference state camp. Methods of selection for the roles of chief of the tribe and sagamore of the tribe vary by county. Nine respondents $(6.5 \%)$ had been chief of their $4-\mathrm{H}$ camp tribe, while twenty $(14.4 \%)$ had been a sagamore of their $4-\mathrm{H}$ tribe.

4-H members attending local and/or state camping programs also may qualify for certain awards given out at the end of each camp. The H awards (Head, Heart, Hands \& Health) and the Spirit of Camp award are typically given to campers at the last camp gathering to recognize outstanding campers. Responses indicated that 28 (20.1\%) had received an $\mathrm{H}$ award at camp. Five (3.6\%) respondents indicated receiving the Spirit of Camp Award, the highest honor given at camp. An additional question concerning whether participants had been an officer in their local 4-H club was asked. Eighty three (59.7\%) participants indicated being elected as an officer for their 4-H club.

\section{YLLSDS Response Ratings}

The Youth Leadership Life Skills Development Scale consisted of 30 questions asking respondents to rate their perceived gain of leadership life skill development as a result of 4-H camping involvement. Respondents rated each statement on a scale of $\mathrm{A}$ to $\mathrm{D}(\mathrm{A}=\mathrm{No}$ Gain, $\mathrm{B}=$ Slight Gain, C = Moderate Gain, D = A Lot of Gain). For purposes of statistical analysis, the 
researcher recoded the data $(0=$ No Gain, $1=$ Slight Gain, $2=$ Moderate Gain, $3=$ A Lot of

Gain). The total YLLSDS score was calculated by summing responses for each item.

Table 7

Mean Importance Ratings and Standard Deviations for the Youth Leadership Life Skill

Development Scale Items

\begin{tabular}{llc}
\hline Item & Mean & Standard Deviation \\
\hline I have a friendly personality & 2.34 & .91 \\
I get along with others & 2.34 & .94 \\
I respect others & 2.29 & .81 \\
I am open minded & 2.27 & .81 \\
I consider the needs of others & 2.25 & .87 \\
I consider input from all group members & 2.22 & .85 \\
I can listen effectively & 2.22 & .88 \\
I show a responsible attitude & 2.19 & .97 \\
I have a positive self-concept & 2.18 & .85 \\
I trust other people & 2.12 & .98 \\
I am sensitive to others & 2.11 & .93 \\
I can be flexible & 2.10 & .82 \\
I can set goals & 2.09 & .81 \\
I have good manners & 2.07 & 1.00 \\
I recognize the worth of others & 2.05 & .94 \\
I can be honest with others & 2.04 & .93 \\
I can express feelings & 2.01 & .97 \\
I am open to change & 1.99 & .99 \\
I can handle mistakes & 1.98 & .90 \\
I can use information to solve problems & 1.97 & 1.07 \\
I can delegate responsibility & 1.97 & .93 \\
I create an atmosphere of acceptance & 1.95 & .94 \\
I can consider alternatives & 1.94 & .83 \\
I can set priorities & 1.88 & .90 \\
I can be tactful & 1.84 & .96 \\
I can select alternatives & 1.83 & .82 \\
I can solve problems & 1.81 & .88 \\
I use rational thinking & 1.81 & .95 \\
I can clarify my values & 1.78 & 1.01 \\
I can determine needs & 1.76 & .79 \\
\hline
\end{tabular}

Rating Scale: $0=$ No Gain; 1=Slight Gain; 2=Moderate Gain; 3=A Lot of Gain 
Among the 30 indicators, respondents indicated the greatest gain for "I have a friendly personality" $(\mathrm{m}=2.34)$, "I get along with others" $(\mathrm{m}=2.34)$, "I respect others" $(\mathrm{m}=2.29)$, "I am open minded" $(\mathrm{m}=2.27)$, and "I consider the needs of others" $(\mathrm{m}=2.25)$. The YLLSDS had a minimum score of 0 and a maximum score of 90 . According to a research report (Dormody et al. 1993) scale values from 0 and 30 may be no to slight leadership life skills development, 31 to 60 moderate development, and 61 to 90 high development. The mean for the overall YLLSDS for this study was 61.37 and was considered high leadership life skills development. A complete list of means and standard deviations of Youth Leadership Life Skills Development Scale items are listed in Table 7.

\section{Analysis of Variance between YLLSDS and Demographic Data}

An ANOVA was run to compare means between YLLSDS total scores and Demographic Data. No significant differences were observed as shown in Table 8.

\section{Table 8}

Analysis of Variance Examining Effects of Age, Ethnicity, Gender, and Place of Residence on Youth Leadership Life Skills Development Total Score.

\begin{tabular}{cccc}
\hline Category & Mean & F & Sig. \\
\hline $\begin{array}{c}\text { Gender }(\mathrm{n}=139) \\
\text { Male }\end{array}$ & 60.01 & 1.171 & 0.28 \\
Female & 63.45 & & \\
& & & \\
Age $(\mathrm{n}=139)$ & & 2.031 & 0.14 \\
13 & 65.95 & & \\
14 & 60.05 & &
\end{tabular}

Ethnic Background ( $\mathrm{n}=136)$

American Indian/Alaskan native

00.00

0.405

0.53

Asian or Pacific Islander

00.00

Black, not of Hispanic origin

00.00

White, not of Hispanic origin

61.23

Hispanic

73.00 
Residence $(\mathrm{n}=138)$

Farm

63.02

0.540

0.66

Town or rural non-farm area

59.44

Larger Town

64.30

City or suburb of a city

61.00

Rating Scale: $0=$ No Gail; 1=Skight Gain; 2=Moderate Gain; 3=A Lot of Gain

Analysis of Variance between YLLSDS and 4-H related variables

An ANOVA was run to examine differences between means of the YLLSDS total score

and all 4-H related variables. Receiving the Spirit of Camp Award did show significance as reported in Table 9.

Table 9

Analysis of Variance Examining 4-H related variables on Youth Leasdership Life Skills Development Total Score.

\begin{tabular}{llll}
\hline Variable & Mean & F & Sig. \\
\hline $\begin{array}{c}\text { Chief of Tribe } \\
\text { Yes }\end{array}$ & 71.33 & 2.995 & 0.09 \\
No & 60.53 & &
\end{tabular}

Sagamore of Tribe

$\begin{array}{llll}\text { Yes } & 67.35 & 2.625 & 0.11 \\ \text { No } & 60.20 & & \end{array}$

Spirit of Camp Award

$\begin{array}{llll}\text { Yes } & 36.20 & 10.318 & 0.00^{*} \\ \text { No } & 62.18 & & \end{array}$

H Award

$\begin{array}{llll}\text { Yes } & 64.64 & 1.211 & 0.27 \\ \text { No } & 60.37 & & \end{array}$

Club Office

$\begin{array}{llll}\text { Yes } & 61.01 & 0.032 & 0.86\end{array}$

No 61.58

Rating Scale: 0=No Gain; 1=Slight Gain; 2=Moderate Gain; 3=A Lot of Gain

Correlation of YLLSDS Total Score with 4-H related variables

The Pearson product-moment coefficient of correlation was used to determine if a significant relationship existed between total YLLSDS score and 4-H related variables. This test 
gives a ratio, or $r$ value, which identifies the extent to which changes in one variable are accompanied by, or are dependent upon changes in a second variable. The relationship of variables is expressed by a scale that ranges from -1.00 to +1.00 . The significance of the resulting $\mathrm{r}$ value is tested against the null hypothesis that the population $\mathrm{r}$ is in fact zero (no relationship exists). An $\mathrm{r}$ value significant at the 0.05 level of confidence means that only 5 times out of 100 would a value of such magnitude be observed from fluctuations in sampling in the population $r$ were zero.

The strength of these Pearson Product-Moment correlation coefficients are described based on the following scale by Davis (1971): a coefficient of 0.70 or higher: very strong relationship; a coefficient of 0.50 to 0.69 : substantial relationship; a coefficient of 0.30 to 0.49 : moderate relationship; a coefficient of 0.10 to 0.29 : low relationship; a coefficient of 0.01 to 0.09: negligible relationship.

A significant relationship was found between the Years at County 4-H camp variable and the YLLSDS variable. A summary of correlations for these variables is provided in Table 10.

Table 10

Correlations of the YLLSDS with selected 4-H Variables.

\begin{tabular}{ll}
\hline Variable & r value \\
\hline & \\
Years in 4-H & 0.16 \\
Years at County 4-H Camp & $0.27^{*}$ \\
Years of Teen Leadership & 0.06 \\
Years of Leadership Project & 0.07 \\
\hline
\end{tabular}

*Correlations are Significant at the .05 level of confidence 


\title{
CHAPTER V
}

\author{
Summary, Conclusions, Recommendations
}

The purpose of this study was to investigate relationships that exist between youth leadership life skill development and 4-H camp participation. 4-H members participating in the 1998-1999 club year, ages 13 through 15, were asked about their 4-H camping participation and leadership life skill development as it relates to their 4-H camping experiences. The results of this study will be provided to Extension Service personnel to assist with statewide planning and evaluation of 4-H camping programs. Results will also be provided to county Extension agents to reinforce countywide camping program development and evaluation aimed at increasing youth development objectives in the area of leadership development.

Objectives of the Study

9. Describe the respondents' demographic characteristics related to age, gender, ethnicity, and place of residence.

10. Describe respondents' self-perceived gain of leadership life skill development as a result of the 4-H camping experience measured by the Youth Leadership Life Skills Development Scale.

11. Determine the relationships between members' self-perceived gain of leadership life skill development and age, ethnicity, gender, place of residence.

12. Determine the relationship between participation in the 4-H camping program and members' self-perceived gain of leadership life skills development by examining years in 4-H, years at 
county camp, years at state camp, teen leadership, being elected as an officer of a 4-H club, being a chief or sagamore of a 4-H tribe, or receiving specific awards.

The population for this study was all 4-H members participating in the camping program between the ages of 13 and 15 as of the 1998-1999 club year who live in West Virginia. . A simple random sampling method was used to obtain desired information from $4-\mathrm{H}$ members excluding the counties of Lewis and Braxton in West Virginia. For purposes of collecting data, 400 surveys were mailed to current 4-H members with usable questionnaires returned by 139 participants.

The survey instrument utilized in this study was "Assessing Leadership Skills Gained Through the West Virginia 4-H Camping Program." The survey form consisted of two parts. Part one of the survey inquired about the development of youth leadership life skills, using the original Youth Leadership and Life Skills Development (YLLSDS) questionnaire developed by Dormody, Seevers, and Clason (1993). Written permission from the authors was obtained to replicate the YLLSDS instrument for this study. Part two of the survey deals with age, gender and demographic information and information related to 4-H camping involvement.

Characteristics of early and late respondents were compared and no significant differences were found between groups. Characteristics of the respondents were as follows: Over $60 \%$ of the respondents were female, while nearly $40 \%$ were males. When examining place of residence, $32 \%$ of the respondents lived on farms and over $50 \%$ lived in small towns.

Nearly $25 \%$ of 13 to 15 year olds had been in $4-\mathrm{H}$ for 7 years. The most common response for years at camp, however was attendance for 2 years and attendance at a state camp was limited to $25 \%$ of respondents for any length of time. 
The majority (61\%) of respondents had never been a teen leader and $72 \%$ had never taken the leadership project offered by $4-\mathrm{H}$. Nearly $60 \%$ of respondents did indicate participating as a club officer at their local 4-H club during their 4-H tenure.

Participants were asked to rate their self-perceived gain of Leadership Life Skills as a result of their participation in the 4-H camping program using the Youth Leadership Life Skills Development Scale. Among the 30 indicators of the scale, respondents indicated highest ratings for "I have a friendly personality," "I get along with others," "I respect others," "I am open minded," and "I consider the needs of others."

No significant relationships were found between age, ethnicity, gender, place of residence, and YLLSDS total score as examined by the analysis of variance procedure (ANOVA). When comparing YLLSDS total score with 4-H related variables such as chief or sagamore of tribe or awards received at camp also using an ANNOVA, a significant relationship was found between YLLSDS total score and receiving the Spirit of Camp award.

Pearson Product Moment correlations examined between the YLLSDS score and 4-H related variables yielded a significant relationship between YLLSDS score and years at 4-H camp.

\section{Conclusions}

Based upon the results of this study, the following conclusions were drawn:

- Few 4-H members are engaging in leadership building programs such as Teen Leaders or taking the Leadership Project as evidenced by participation levels in those programs.

- Females rated themselves as receiving higher leadership life skills gain than did males.

- Participants in the West Virginia Camping Program rated themselves as having high gain of leadership life skills as a result of their experiences in that program. 
- The self-perceived gain of leadership life skills decreased with age in this study. 13 year olds had the highest YLLSDS score with 14 and 15 year olds following respectively.

- 4-H campers who had served as a chief or sagamore rated their gain of leadership life skills much higher than those who had not received that award.

- While receiving the Spirit of Camp Award was significant, recipients rated their leadership life skills much lower than those who had not received the award.

- 4-H campers who had received an H Award rated their leadership life skills slightly higher than those who had not received that award.

- Campers serving as an officer in their 4-H club rated their leadership life skills at nearly the same as those who have not held an office in their 4-H club.

- Years at county 4-H camp are significantly related to higher gains in leadership skills. The correlation is low, however.

\section{Recommendations}

1. County Extension Agents and Volunteer Leaders should promote participation in leadership activities such as the Teen Leadership program and taking the leadership project. Previous research has indicated problems with the leadership project materials in that children reported the materials to be lengthy and that hands on leadership opportunities were not offered project. Agents and volunteers should review existing materials associated with the leadership project.

2. The results of this study indicate that younger 4-H camping participants rate their leadership life skills gain higher than do older participants. Research needs to be conducted to further investigate this finding. 
3. Research is needed to determine leadership goals for the 4-H camping program. Statewide standards for leadership development need to be examined to better develop leadership life skills in the 4-H camping program.

4. Participants rated their gain of leadership life skills higher when serving as chief or sagamore of a tribe, however, those participants who had served as a 4-H club officer rated their gain nearly the same as those who had not served as an officer. Further investigation into this finding should be conducted to better understand how leadership is developed in the club versus camp setting.

5. Participants receiving awards at 4-H camp with the exception of the Spirit of Camp Award rated their leadership life skills gain higher than those who did not. County Extension Agents should evaluate the basis for receiving these awards and develop uniform standards for giving these awards to camping participants.

6. Overall, vast inconsistencies exist in the leadership goals, opportunities, and awards county by county in the West Virginia 4-H Camping Program. Basic camp planning and implementation guidelines need to be established at the state and county level to foster the development of leadership life skills in the West Virginia 4-H Camping Program. 


\section{References}

Adams, G.R. \& Gulotta, T. (1983). Adolescent Life Experiences. Monterey, CA. Brooks/Cole Publishing.

Astroth, K. A. (December, 1996). Leadership in Nonformal Youth Groups: Does Style Affect Youth Outcomes? Journal of Extension [On-line]

Http://joe.org/joe/1996december/rb2.html

Ary, D., Jacobs, L.C., \& Razavieh, A. (1990). Introduction to Research in Education. Ft. Worth, TX. Holt, Rinehart, and Winston, Inc.

Borg, W.R. \& Gall, M.D. (1989). Educational Research: An Introduction. (5 ${ }^{\text {th }}$ ed.). New York: Longman.

Boyd, B. L., Herring, D. R., \& Briers, G. E. (Winter, 1992). Developing Life Skills in Youth, How 4-Hers perceive their leadership. Journal of Extension. [On-line] http://joe.org/joe/1992winter/a4.html

Carnegie Corporation of New York. (1992). A Matter of Time: Risk and Opportunity in the Nonschool Hours. New York, NY.

Conrad, D. (1979). Experiential Education: A Summary of its Theoretical Foundations and a Critical Review of Recent Research. St. Paul, MN. University of Minnesota, Center of Youth Development and Research. July. (ERIC Document Reproduction Service, ED 223 765).

Conrad, D. \& Hedin, D. (1981). National Assessment of Experiential Education: A Final Report. St. Paul, MN. University of Minnesota, Center of Youth Development and Research. (ERIC Document Reproduction Service, ED 233 765).

Dillman, D. (1978). Mail and Telephone Surveys: The Total Design Method. New York, NY. John Wiley and Sons.

Dormody, T.J., Seevers, B.S., \& Clason, D.L. (1993). The Youth Leadership Life Skills Development Scale: An Evaluation and Research Tool for Youth Organizations. New Mexico State University. Research Report 672.

Dormody, T.J., Seevers, B.S., \& Clason, D.L. (1995). Developing A Scale To Research and Evaluate Youth Leadership Life Skills Development. Journal of Agricultural Education, 36.

Durall, J.K. (1997, Jan./Feb.). Curative Factors in the Camp Experience: Promoting Developmental Growth. Camping Magazine, 70 .

Erikson, E. (1968). Identity: Youth and Crisis. New York, NY. Norton. 
Gay, L. (1987) Educational Research: Competencies for Analysis and Application (4 ${ }^{\text {th }}$ ed.). New York, Macmillan Publishing Company.

Glenn, H.S. \& Nelson, J. (1987). Raising Children for Success: Blueprints and Building Blocks for Developing Capable People. Fair Oaks, CA. Sunrise Press.

Hamburg, B.A. (1989). Life Skills Training: Preventive Interventions for Early Adolescents. Report for the Life Skills Training Working Group. New York, NY. Carnegie Council on Adolescent Development.

Havinghurst, R.J. (1972). Developmental Tasks and Education ( $3^{\text {rd }}$ ed.). New York. David McKay Company, Inc.

Hedin, Diane (1983) The Impact of Experience on Academic Learning: A Survey of Theories and Review of Recent Research. Boston: Institute for Responsive Education.

Hendricks, P.A. (1996). Developing Youth Curriculum Using The Targeting Life Skills Model. Ames, Iowa. Iowa State University Extension. [Ongoing Publication].

Jackson, T. (1997). Why should kids join? University of Illinois at Urbania-Champaign. [On-line] Http://www.ag.uiuc.edu/ fourh/clover/DOES4BG.HTM

Kaplin, P.S. (1991). A Child's Odyssey (2 ${ }^{\text {nd }}$ ed.). St. Paul, MN: West Publishing Co.

Krejcie, R.V. \& Morgan, D.W. (1970). Determining Sample Size for Research Activities. Educational and Psychological Measurement, 30 607-608.

Lang, C.L., \& Gerwig, J.L. (1989). The Ever Growing Clover. NAE4-H News and Views, $\underline{42}(4), 6-8$.

Leffert, N., Benson, P.L., \& Roehlkepartain, J.L. (1997). Starting Out Right:

Developmental Assets for Children. Search Institute. Minneapolis, MN. Search Institute.

Lerner, Richard M. (1993). Early Adolescence, Perspectives on Research, Policy, and Intervention. New Jersey: Lawrence Erlbaum Associates.

Miller, J.P. (1991a). Four-H and Non-4-H Participants' Development of Competency, Coping, and Contributory Life Skills. Unpublished doctoral dissertation. University Park: The Pennsylvania State University.

Miller, J.P. (1991b). Linking 4-H youth development programs with adolescent developmental theory: A review of literature. Agricultural and Extension Education Research

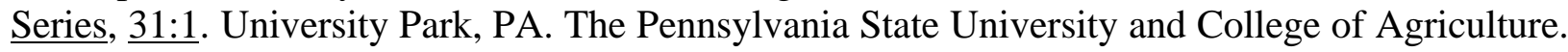

Miller, L. \& Smith, K. (1983, September/October). Handling Non-response Issues. Journal of extension, 21, (5) 45-50. 
Miller, R.A. (1975). Life Skills for 4-H Leadership Roles. Unpublished master's thesis, Oklahoma State University, Stillwater.

Miller, R.A. (1976). Leader/Agent's Guide: Leadership Life Skills. Stillwater: Oklahoma State University.

Morris, J.C. (1996). Self-perceived Youth Leadership Life Skills Development Among Iowa 4-H Members. Unpublished doctoral dissertation. Iowa State University, Ames, Iowa.

National 4-H Council. Objective of 4-H. [Online]. http://www.fourhcouncil.edu

O’Brien, L., Pavlicin, K., Lister, R., \& Schultz, B. (1995, Nov./Dec.). Expressing Camp, Part 1, The Developmental Needs of Young People. Camping Magazine, 68.

Report to the Nation. Executive Summary. [Online]

http://www.americaspromise.org/NE4c.htm

Sauter, S. (1993). Selected 1993 highlights. You've Seen the Helping Hand of Extension [Annual Report].

Scales, P. (1986). Forward to the Basics - Life Skills Education for Today's Youth. Family Life Educator, 5(3), 4-9.

Schlutt, Jr., E.F. (1987). Impact of Youth Program Membership on Youth Program Life Skills Development, Youth Program Experiences, Adult Community Participation, and Personal Characteristics Related to 4-H Volunteerism. Doctoral dissertation. College Station. Texas A \& M University.

Search Institute (1997). Five Fundamental Resources for Children and Youth, America's Promise-The Alliance for Youth. Minneapolis, MN.

Search Institute (1997). Five Fundamental Resources for Children and Youth. America's Promise; The Alliance For Youth. Minneapolis, MN. Search Institute.

Small Sample Techniques (1960). The NEA Research Bulletin, Vol. 38, p. 99.

Stewart, G.H. (1969). A Touch of Charisma: A history of the 4-H Program in West Virginia. Morgantown: West Virginia University Extension Service.

This is 4-H: Philosophy and Traditions (1967). West Virginia University Cooperative Extension Service 4-H project book.

Thomas, H. (Mar-Apr 1996). Youth Leadership: Teaching Essential Proficiencies at Camp. Camping Magazine, $\underline{68}$ 25-27. 
United States Department of Agriculture (USDA). Extension Service. (1983). Camping Handbook. Washington DC: Author.

United States Department of Agriculture (USDA). Extension Service. (1994). Focus on the Future: A Strategic Plan for 4-H and Youth Development. Washington DC: Author.

Van Horn, J.E. (1986). Adolescent Self Concept-Overview. The Family and Economic Well Being National Database. University Park. The Pennsylvania State University, College of Agriculture.

Waguespack, B.G. (1988). Development of Life Skills of 4-H Club Members in Louisiana. Unpublished master's thesis. Baton Rouge. Louisiana State University.

Walker, J. \& White, L. (1998, Winter). Caring Adults Support the Healthy Development of Youth. The Center for 4-H Youth Development at the University of Minnesota. St. Paul, MN. University of Minnesota Extension Service.

Weatherford, David and Peck, Sue (1983). Extension's 4-H: Toward the '90's. Extension Service, USDA. Washington, D.C.

Weatherford, D. \& Weatherford, C. (1987). A Review of Theory and Research Found in Selected Experiential Education, Life Skill Development and 4-H Program Impacts Literature. Raleigh, NC. North Carolina State University, United States Department of Agriculture and National 4-H Council. 


\section{APPENDIX A}

Cover Letter to 4-H Members

February 1, 1999

Dear 4-H Member: 
I am a graduate student at West Virginia University earning a Master's Degree and studying to become an Extension Agent, and I would like your help. As part of the completion of my degree, I am conducting research about youth leadership development and 4-H camping in West Virginia. I was a 4-Her and would like to use the information I am collecting to improve 4-H camps.

You have been chosen to participate in my study to help improve the West Virginia 4-H camping program. Because you are in $4-\mathrm{H}$, your opinions are valuable to me, and I would like to know what you think about 4-H camp and what you have learned. Some 4-H members have not attended camp; if you haven't, I want to know how you feel about being a 4-H member.

The enclosed survey asks questions about camp, yourself, and 4-H. Please tell me what you think by filling out the survey. First, get one of your parents or guardians to sign the consent forms enclosed. Your parents should keep the blue copy and return the yellow copy to me. Then, you need to sign the assent forms, keeping the blue for yourself and returning the yellow copy to me. If the forms are not signed, I cannot use your information in my study, so please make sure you and your parent or guardian sign the forms. It will take you approximately 10 minutes to complete the survey. This is completely voluntary and you will in no way be penalized for choosing not to participate. Please be as honest as possible. Information you provide will be kept confidential and there are no wrong answers.

If there are any questions that make you uncomfortable, you do not have to answer them. However, the more information you can give me the more it will help me in my research and improve 4-H in West Virginia. When you complete the survey, place it and the yellow consent and assent forms in the postage paid return envelope and mail it to me within one week. Please accept the enclosed 4-H sticker and my appreciation for your time and filling out my survey.

When all the surveys have been returned to me, they will be analyzed to see what members think about 4-H camps and leadership. The results will be made available to extension personnel and 4-H leaders to assist them in planning 4-H camps.

Thank you very much for your time and effort! You will be helping me to improve 4-H camping programs in West Virginia.

Sincerely,

Rebecca Duncan, Master's Degree Candidate
Stacy A. Gartin

Professor 


\section{APPENDIX B}

Cover Letter to Parents

Dear 4-H Parent: 
I am a WVU Extension Specialist with the division of 4-H and Youth, Family, and Adult Development. Rebecca Duncan, a graduate student at West Virginia University earning a Master's Degree and studying to become an Extension Agent is interested in the benefits of participating in the 4-H program. Rebecca is conducting research about youth leadership development and 4-H camping in West Virginia and would like to use the information to improve 4-H camps and the 4-H program in general.

Your child has been chosen from over 2000 children to participate in Rebecca's study. Your child may not attend 4-H camp, but their information is still very valuable to this study and I would ask that you encourage your child to participate. Your county Extension Agent has approved this study and believes it to be important.

Enclosed with this letter is a letter to your child from Rebecca and her Advisor, two copies of forms for you and your child to sign, and the survey itself. The yellow form attached to the survey must have your signature and your child's signature for Rebecca to use the survey information. The blue copy is for you to keep. Your child does not have to participate in this study and will not be penalized for choosing not to participate.

The enclosed survey asks questions about camp, your child, and 4-H. It will take approximately 10 minutes to complete the survey. Even if your child does not attend 4-H camp, it is important they fill out the survey. If you have any questions about the forms, the survey, or the study contact Rebecca Duncan or me at (304) 293-2694 at (304) 293-2694 or (304) 598-0768 in the evenings. Information provided will be kept confidential; your child's name will never appear on any information. When the study is complete, Rebecca will report the results to your county Extension Agent and other Extension personnel and 4-H leaders to assist them in planning 4-H camps and other 4-H programs.

Thank you very much for your time and effort! You will be helping to improve 4-H and camping programs in West Virginia.

Sincerely,

Patty Mulkeen 
APPENDIX C

Consent Form

4-H Camp and Leadership Development 


\section{Parental Consent Form}

I, , have been asked to allow my child, , to participate in this study. Rebecca Duncan, is conducting

this research to fulfill the requirements for a masters degree in Agricultural and Extension Education at West Virginia University.

The objective of this study is to determine to what extent the West Virginia 4-H Camping Program helps youth develop leadership skills. This study will require a questionnaire to be completed, and will take 10 minutes. I have been given an opportunity to examine the questionnaire. Approximately 700 4-H members will take part in this study.

There are no risks from participating in this study. I understand that this study is not expected to be of direct benefit to my child, but the knowledge gained may be of benefit to $\mathrm{him} / \mathrm{her}$, and others.

For more information about this research, I can contact Rebecca Duncan at 293-2694 during the day or 598-0768 in the evenings. I may also contact her advisor Dr. Stacy Gartin at 293-4832 ext. 4480 or supervisor Dr. Patty Mulkeen at 293-2694. For information regarding my child's rights as a research subject, I may contact the Executive Secretary of the Institutional Review Board at 293-7073.

I understand that any information obtained as a result of my child's participation in this research will be kept confidential and that participation in the study is voluntary. I understand that my child is free to withdraw from this study at any time. Refusal to participate in or withdrawal from this study will involve no penalty or loss of benefits for me or my child.

I willingly consent to my child's participation in this study.

Signature of Parent/Guardian

Signature of Investigator
Date

Date 
APPENDIX D

Assent Form

4-H Camp and Leadership Development 


\section{Assent Form}

I, research study. , have been asked to participate in this

I have been told that the purpose of this study is to learn more about 4-H, 4-H camping, and leadership development.

This study will be performed in my home, and I will be given written questions to answer. It will take about 10 minutes for me to answer all of the questions.

I understand that this study is not expected to help me, but what they learn from the study may help other people.

I have been promised that anything they learn about me in this study will be kept confidential.

I have been told that I do not have to do this. No one will be mad at me if I refuse to do this or if I decide to quit. I have been allowed to ask questions about the research by calling Rebecca Duncan at 293-2694 or 598-0768.

I willingly agree to be in this study.

Signature of Subject

Signature of Investigator
Date

Date 
APPENDIX E

Survey 


\section{YOUTH LEADERSHIP LIFE SKILL DEVELOPMENT $\mathrm{OF}$ \\ PARTICIPANTS IN THE WEST VIRGINIA 4-H \\ CAMPING PROGRAM}

Survey

\section{Instructions:}

Based on your 4-H camping experiences, circle the letter that best represents how 4-H camp has influenced you for each questions. If you do not attend 4-H camp, circle the letter that best represents how 4-H clubs have influenced you for each question. Please circle only one letter per question. The following is an example.

As a result of my 4-H experiences I: $\begin{array}{r}\text { No } \\ \text { Gain }\end{array} \underset{\text { Gain }}{\text { Slight }} \begin{gathered}\text { Moderate } \\ \text { Gain }\end{gathered}$ Lot of 1. Can get along with adults $\quad$ A $\quad$ B $\quad$ C $\quad$ D

If 4-H (or 4-H camp) has not helped you to get along with adults, you should circle A. If 4-H (or 4-H camp) has helped you to get along really well with adults, you should circle D. Remember there are no wrong answers and all answers will remain confidential.

Thank you for participating in my study! 


\section{Youth Leadership Life Skills Development Scale}

What leadership skills have you improved because of your 4-H_involvement? Please answer every question.

As a result of my 4-H experiences I: No SlightModerate A Lot of Gain Gain Gain Gain

1. Can determine needs

2. Have a positive self-concept

3. Can express feelings

4. Can set goals

5. Can be honest with others

6. Can use information to solve problems

7. Can delegate responsibility

8. Can set priorities

9. Am sensitive to others

10. Am open minded

11. Consider the needs of others

12. Show a responsible attitude

13. Have a friendly personality

14. Consider input from all group members $A$

15. Can listen effectively

16. Can select alternatives

17. Recognize the worth of others

18. Create an atmosphere of acceptance

19. Can consider alternatives

20. Respect others

21. Can solve problems

22. Can handle mistakes

23. Can be tactful

24. Can be flexible

25. Get along with others

26. Can clarify my values

27. Use rational thinking

28. Am open to change

29. Have good manners

30. Trust other people

$\begin{array}{llll}\text { A } & \text { B } & \text { C } & \text { D } \\ \text { A } & \text { B } & \text { C } & \text { D } \\ \text { A } & \text { B } & \text { C } & \text { D } \\ \text { A } & \text { B } & \text { C } & \text { D } \\ \text { A } & \text { B } & \text { C } & \text { D }\end{array}$

$\begin{array}{llll}\text { A } & \text { B } & \text { C } & \text { D }\end{array}$

$\begin{array}{llll}\text { A } & \text { B } & \text { C } & \text { D }\end{array}$

$\begin{array}{llll}\text { A } & \text { B } & \text { C } & \text { D }\end{array}$

$\begin{array}{llll}\text { A } & \text { B } & \text { C } & \text { D }\end{array}$

$\begin{array}{llll}\text { A } & \text { B } & \text { C } & \text { D }\end{array}$

$\begin{array}{llll}\text { A } & \text { B } & \text { C } & \text { D }\end{array}$

$\begin{array}{llll}\text { A } & \text { B } & \text { C } & \text { D }\end{array}$

$\begin{array}{llll}\text { A } & \text { B } & \text { C } & \text { D }\end{array}$

$\begin{array}{llll}\text { A } & \text { B } & \text { C } & \text { D }\end{array}$

$\begin{array}{llll}\text { A } & \text { B } & \text { C } & \text { D }\end{array}$

$\begin{array}{llll}\text { A } & \text { B } & \text { C } & \text { D }\end{array}$

$\begin{array}{llll}\text { A } & \text { B } & \text { C } & \text { D }\end{array}$

$\begin{array}{llll}\text { A } & \text { B } & \text { C } & \text { D }\end{array}$

$\begin{array}{llll}\text { A } & \text { B } & \text { C } & \text { D }\end{array}$

$\begin{array}{llll}\text { A } & \text { B } & \text { C } & \text { D }\end{array}$

$\begin{array}{llll}\text { A } & \text { B } & \text { C } & \text { D } \\ \text { A } & \text { B } & \text { C } & \text { D } \\ \text { A } & \text { B } & \text { C } & \text { D } \\ \text { A } & \text { B } & \text { C } & \text { D } \\ \text { A } & \text { B } & \text { C } & \text { D }\end{array}$

$\begin{array}{llll}\text { A } & \text { B } & \text { C } & \text { D } \\ \text { A } & \text { B } & \text { C } & \text { D } \\ \text { A } & \text { B } & \text { C } & \text { D } \\ \text { A } & \text { B } & \text { C } & \text { D } \\ \text { A } & \text { B } & \text { C } & \text { D }\end{array}$




\section{About You}

31) What is your gender?
A. Female
B. Male

32) What is your age today?
A. Under 13
B. 13
C. 14
D. 15
E. Over 15

33) What is your ethnic background?
A. American Indian or Alaskan Native
B. Asian or Pacific Islander
C. Black, not of Hispanic origin
D. White, not of Hispanic origin
E. Hispanic

34) What category best describes where you live?
A. Farm
B. Town or rural non-farm area
C. Larger town (such as Beckley, Bluefield, Clarksburg, Fairmont, Martinsburg, Morgantown, Moundsville, Parkersburg, St. Albans, South Charleston, Vienna, Weirton, Wheeling)
D. City or suburb of a city (such as Charleston or Huntington)

35) Are you currently a 4-H member?
A. Yes
B. No

36) How many years have you been in 4-H since you were 8 years old?
A. 1 Year
F. 6 Years
B. 2 Years
G. 7 Years
C. 3 Years
D. 4 Years
E. 5 Years

37) How many years have you been to county 4-H camp since you were 8 years old?
A. 0 Years
F. 5 Years
B. 1 Year
G. 6 Years
C. 2 Years
H. 7 Years
D. 3 Years
E. 4 Years 
38) How many years have you been to a State 4-H camp since you were 8 years old?
A. 0 Years
F. 5 Years
B. 1 Year
G. 6 Years
C. 2 Years
D. 3 Years
E. 4 Years

39) How many years have you been a teen leader?
A. 0 Years
B. 1 Year
C. 2 Years
D. 3 Years

40) How many years have you taken the Leadership 4-H Project?
A. 0 Years
B. 1 Year
C. 2 Years
D. 3 Years

41) Have you ever been chief of your tribe at 4-H Camp?
A. Yes
B. No

42) Have you ever been sagamore of your tribe at 4-H camp?
A. Yes
B. No

43) Have you ever been spirit of 4-H Camp?
A. Yes
B. No

44) Have you ever been chosen for an $\mathrm{H}$ award at 4-H Camp (Head, Heart, Hands, or Health)?
A. Yes
B. No

45) Have you ever held an office in your 4-H club?
A. Yes
B. No 